\section{YUMEKO KAWAMOTO}

Tokyo University of Foreign Studies

https://orcid.org/0000-0002-6571-8676
Copyright and License: Copyright by Instytut Języka Polskiego PAN, Kraków 2021. This article is published under the terms of the Creative Commons Attribution - NoDerivatives 4.0 International (CC BY- ND 4.0) License (https:// creativecommons.org/licenses/by-nd/4.0/legalcode.pl).

\title{
RELACJA NA TY W ŚWIETLE TEKSTÓW Z NARODOWEGO KORPUSU JĘZYKA POLSKIEGO
}

Słowa kluczowe: formy adresatywne, korpus języka polskiego, przejście na ty, relacje międzyludzkie.

\section{STRESZCZENIE}

Artykuł przedstawia analizę tekstów korpusowych opisujących relację na ty w polskim społeczeństwie. Materiał badawczy stanowi ponad 600 tekstów z hasłem na ty oraz per ty zaczerpniętych z Narodowego Korpusu Języka Polskiego, które pozwalają zobrazować ogólny zarys relacji na ty. Zaprezentowana analiza pokazuje, że w relacji na ty istnieje jedna lub więcej z trzech więzi między rozmówcami: więź dla korzyści, więź dla swobody oraz więź uczuciowa. Więź dla korzyści łączy interlokutorów w realizowaniu wspólnego celu i taką relację na ty czasami można obserwować w środowisku politycznym. Niektóre teksty pokazały, że w dążeniu do swobody w interakcji również rodzi się więź łącząca osoby przechodzące na ty, a więź uczuciowa może dotyczyć rodziny czy długo znających się rozmówców. Przejście na ty można traktować jako akt potwierdzający istnienie jednej lub kilku z wyżej wymienionych więzi, nie zawsze jest on jednak równoznaczny z pozwoleniem na przekroczenie granicy prywatności. Wyniki analizy dowiodły również, że wyznaczniki społeczne takie jak wiek, hierarchia czy płeć mogą spowodować poczucie skrępowania przy przejściu na ty. Zasygnalizowane przez niniejszą analizę elementy stanowią istotną bazę do dalszych badań przedmiotu.

\section{WPROWADZENIE}

Podział między relacją na ty a relacją na pan/pani jest ciągle aktualnym przedmiotem zainteresowań językoznawców i w publikacjach polonistycznych można znaleźć opisy tych dwóch relacji na różnych płaszczyznach języka. Sposób traktowania niniejszej tematyki może wywołać kontrowersję ze względu na charakterystykę socjolingwistyki pokrywającą się z charakterystyką socjologii języka. Socjolingwistyka stanowi dosyć nową dyscyplinę naukową - ukształtowaną w drugiej połowie XX wieku. Kwiryna Handke wspomina o zakresie badawczym socjolingwistyki w porównaniu z przedmiotem badań socjologii języka:

Współcześnie niekiedy utożsamia się zakresy socjologii języka i socjolingwistyki, kiedy indziej odróżnia, twierdząc, że tam, gdzie punktem wyjścia jest socjologia, mamy do czynienia z socjologią języka, a tam, gdzie punktem wyjścia jest językoznawstwo, mamy do czynienia z socjolingwistyką $(2021,13)$. 
Z powyższego stwierdzenia wynika, że wybór jednej z tych dwóch dyscyplin zależy przede wszystkim od zainteresowań naukowych badacza oraz od perspektywy, z której obserwuje on zjawiska językowe. Dyskusje na temat podziału między relacją na ty a relacją na pan/pani najczęściej traktuje się jako przedmiot badań lingwistycznych (niekiedy - socjolingwistycznych), ponieważ te relacje decydują o podstawowej formie osobowej w komunikacji językowej. Andrzej Markowski wspomina o tym podziale w odniesieniu do sposobu zwracania się do drugiej osoby - pisze, że w komunikacji w języku polskim

[...] uniwersalną formułą zwracania się do osoby dorosłej, z którą nie jest się „na ty”, jest posługiwanie się zaimkami grzecznościowymi w formie (równobrzmiącej z rzeczownikami) pan, pani, państwo, panie, panowie $(2018,109)$.

Wspominane tutaj użycie zaimków grzecznościowych ${ }^{1}$ wpływa również na inne środki językowe, przede wszystkim - na fleksyjne ${ }^{2}$. Kiedy rozumiemy relację na ty i relację na pan/pani jako elementy decydujące o formie językowej w danej sytuacji komunikacyjnej, dyskusje na temat podziału między użyciem ty a użyciem pan/pani stają się więc przedmiotem badań lingwistycznych. Tak jak twierdzi angielski lingwista Richard A. Hudson, ,wartość socjolingwistyki polega na świetle, jakie rzuca ona na naturę języka w ogóle lub na cechy charakterystyczne konkretnego języka" (1996, 4). Można zatem powiedzieć, że zarówno relacja na ty, jak i relacja na pan/pani należą do zakresu socjolingwistyki jako temat badawczy, który odzwierciedla związek istniejący między językiem a życiem społecznym.

Podstawę dyskusji na temat podziału między relacją na ty a relacją na pan/pani stanowią semantyka władzy oraz semantyka solidarności, które to terminy wprowadzili Roger Brown i Albert Gilman (1960). Marek Łaziński w swojej monografii przedstawia je w następny sposób:

Semantyka władzy funduje system, w którym osobie wyżej postawionej przysługuje zaimek grzeczny
[...], a osobie niżej postawionej przysługuje zaimek bezpośredni [...]. Semantyka solidarności tworzy
system, w którym używa się zaimków formalnych - V, jeśli rozmówcy nie znajdują wystarczająco
silnego czynnika integrującego, w pozostałych przypadkach stosuje się T $(2006,19)$.

Brown i Gilman odnoszą się głównie do języków zachodnioeuropejskich i opisują istniejącą w nich opozycję $\mathrm{T}$ (łac. tu) - V (łac. vos), którą można by również stosować

\footnotetext{
${ }^{1} \mathrm{~W}$ polskiej gramatyce nie traktuje się formy pan/pani jako zaimków, jednak w niektórych artykułach czy monografiach naukowych autorzy opisują je jako zaimki (Łaziński 2006, 15). Określenie zaimki osobowe występuje przede wszystkim w pracach Huszczy $(1980,1996,2000)$, zaimki honoryfikatywne to termin obecny w artykułach Kotikowej (2002) oraz Nowakowskiej (2011). Pisarkowa (1979) i również Łaziński (2006) uznają te jednostki za rzeczowniki, a w opisach Marcjanik (2006, 2014) występuje określenie formy grzecznościowe.

${ }^{2}$ Romuald Huszcza wyróżnia kilka środków językowych, które w polszczyźnie służą do wyrażania honoryfikatywności. Są to - przykładowo - środki stylistyczne i pozastylistyczne, środki leksykalne, środki fleksyjne (zob. Huszcza 1980, 176).
} 
w kontekście polskim. Jako czynniki solidarności - czyli czynniki zwracania się na ty - językoznawca wyróżnia wspólnotę rodzinną, profesjonalną, wspólnotę wieku lub przekonań (Łaziński 2006, 19). O pojęciu wspólnoty w ujęciu relacji na ty wspomina również Antonina Grybosiowa w artykule, w którym skupia się na wspólnocie profesjonalnej, rozumianej jako wspólnota pracy:

[...] mówimy sobie ty (prostsza, krótsza forma adresu), gdyż razem pracujemy. Podstawą wspólnot jest bowiem praca. Zasada ta znosi często blokadę w postaci sporej różnicy wieku dzielącej tradycyjnie rozmówców na takich, z którymi jesteśmy na ty, i takich, z którymi na ty być nie powinniśmy $(2002,5)$.

Innymi słowy: we wspólnocie profesjonalnej, gdzie łączy ludzi praca, rozmówcy decydują się na użycie formy na ty na zasadzie „robimy coś wspólnie”, jednak inne czynniki - takie jak różnica wieku - czasem temu zaprzeczają.

Jeszcze w nieco inny sposób podchodzi do tematu Małgorzata Marcjanik (2007) autorka wielu monografii na temat grzeczności językowej. Badaczka stwierdza, że:

[...] symetryczna relacja na ty w naszej kulturze to przede wszystkim taka relacja między ludźmi, która daje im poczucie pragmatycznej równorzędności. [...] Pomijając różnice indywidualne, [...] bycie na ty jest rodzajem obustronnej zgody na wkraczanie na obszar prywatności drugiej osoby (Marcjanik 2007, 36).

Charakterystyczne dla powyższego stwierdzenia jest to, że zamiast do wspólnot, o których wspomniano w poprzednich cytatach, odnosi się ono do zgody na przekroczenie granicy prywatności. Według Marcjanik relacja władzy oraz relacja solidarności nie są wystarczające do opisania dwóch typów relacji w kontekście polskim (pan/pani oraz ty) i granicę między tymi relacjami należy ująć jako granicę prywatności (Marcjanik 1997, 139). Badaczka dodatkowo rozszerza pojęcie granicy prywatności, gdy odnosi się również do przejścia na ty: „Proponując komuś przejście na ty, mówimy tym samym. że dajemy mu prawo wkraczania na obszar naszej prywatności” (Marcjanik 2006, 274). Według niej to zjawisko jest najczęściej powodowane przez dłuższy kontakt z partnerem rozmowy, a propozycja przejścia na ty „powinna wypłynąć od osoby wyższej rangą, czyli starszej wiekiem, stanowiskiem, lub kobiety" (Marcjanik 2007, 43). O podobnej zasadzie wspomina również Łaziński: ,Wyraźnym śladem semantyki władzy w systemie opartym na semantyce solidarności jest fakt, że to osoba starsza lub wyżej postawiona proponuje młodszej przejście na ty" $(2006,21)$. Wyżej wymienione wyznaczniki społeczne - wiek, status społeczny czy płeć - towarzyszyły Polakom od dawna i wydają się one już znane, jednak brakuje badań uzasadniających obiektywnie tendencję społeczno-językową, o której jest mowa w przytoczonych cytatach z polskich tekstów językoznawczych. Niektóre prace naukowe przedmiotu mają charakter poradnikowy, przez co wymagałyby rewizji zjawisk językowych w nich zdefiniowanych. Możliwa jest niezgoda między zasadami, które są oparte na narzuconym podejściu tradycyjnym w opisach poradnikowych, a rzeczywistym stanem użycia danego języka, i to właśnie ona może powodować dyskomfort w relacjach międzyludzkich w codziennym życiu społecznym. W wielu publikacjach polonistycznych autorzy prowadzą dyskusje na podstawie owoców pracy Marcjanik, jednak niektóre stwierdzenia badaczki mogą być 
już nieaktualne wobec ciągle zmieniającej się rzeczywistości. Jak zauważa Arkadiusz Jabłoński: „Warto przede wszystkim zbadać, z jakiego poziomu, w jaki sposób i w jakich warunkach rzeczywiście następuje akt «przejście na T»" $(2017,134)$. Powyższe rozważania oraz uwagi polskich badaczy sugerują, że relacja na ty jest wielowarstwowa i należy ją rozpatrywać pod kilkoma względami. Chciałabym zatem pogłębić ten temat w dalszej części artykułu - posłuży temu opis analizy danych językowych z perspektywy socjolingwistycznej.

\section{ANALIZA TEKSTÓW Z NARODOWEGO KORPUSU JĘZYKA POLSKIEGO}

Niniejszy artykuł podejmuje próbę analizy tekstów korpusowych w celu opisania relacji na ty w polskim społeczeństwie. Aby zobrazować wielowarstwowość tej relacji, spróbuję przede wszystkim znaleźć odpowiedzi na dwa następujące pytania: (1) jakie znaczenie ma bycie z kimś w relacji na ty; oraz (2) co oznacza przejście na ty i w jakich warunkach ono następuje. Materiał badawczy niniejszej analizy stanowią teksty z bazy Narodowego Korpusu Języka Polskiego (dalej: NKJP), zawierającej bogaty zbiór tekstów zarówno pisanych, jak i mówionych. Teksty zarejestrowane w korpusie nie powstały z myślą o badaniach językowych, w związku z czym jako dane językowe mają pewną wartość obiektywną. Dane korpusowe najczęściej są wykorzystywane do badań w obrębie językoznawstwa tradycyjnego i rzadko stanowią materiał językowy w pracach socjolingwistycznych. Można przypuszczać, że możliwość ustalenia kontekstu sytuacyjnego tylko na podstawie krótkich fragmentów jest w pewnym stopniu ograniczona, ponieważ bazy korpusowe takie jak NKJP nie pokazują całości tekstu danego dzieła literackiego czy artykułu prasowego. Jednak rozpoznanie kontekstu społecznego danej wypowiedzi czy konkretnej sceny jest ciągle możliwe, więc uda się zidentyfikować elementy opisujące relacje międzyludzkie. Pod tym względem dane językowe z bazy korpusu okazują się nieraz wartościowe jako jeden z materiałów badawczych również w zakresie socjolingwistyki.

Przedmiotem analizy jest współczesna polszczyzna po zmianie ustrojowej w Polsce - dlatego wykluczono teksty opublikowane przed 1990 rokiem³. Przeszukanie NKJP z wykorzystaniem dwóch hasel - na ty oraz per ty ${ }^{4}$ - za pomocą wyszukiwarki

\footnotetext{
${ }^{3}$ Po upadku komunizmu polska grzeczność językowa zmieniła się pod wpływem kultury zachodniej. Amerykanizacja społeczeństwa spowodowała tendencję do szybszego skracania dystansu w komunikacji, a polska grzeczność językowa znalazła swoje zastosowanie w relacjach komercyjnych, przykładowo w stosunku do klienta. Anonimowość w mediach społecznościowych również wpływa na zaniedbanie grzeczności w komunikacji (zob. Marcjanik 2015, 115-119; Ożóg 2018, 15-30).

${ }^{4}$ Hasła na ty oraz per ty nie występują tu w rozumieniu terminów słownikowych, a same wyrażenie występują nie w izolacji, ale w połączeniu (przeważnie) z czasownikami. Jednak aby nie przeoczyć niektórych możliwych kolokacji oraz z myślą o koniecznym ograniczeniu zakresu badania, zdecydowałam się na formy na ty oraz per ty. W niniejszym badaniu omijam kolokacje $\mathrm{V}$ po imieniu, ponieważ takie zwroty pojawiają się czasem zupełnie w innym kontekście (np. nazwać coś po imieniu) i komplikują proces badania. Hasła $\mathrm{z}$ użyciem zaimka ty wydają się zatem bardziej bezpośrednio związane z relacją na ty.
} 
PELCRA $^{5}$ zaowocowało uzyskaniem 606 fragmentów opisujących relację z kimś na $t y^{6}$. Frekwencję wystąpienia poszczególnych wyrażeń zawierających hasła na ty oraz per ty pokazuje tabela 1 .

Tabela 1

Liczby wystapień poszczególnych wyrażeń zawierajacych hasła na ty oraz per ty

\begin{tabular}{|l|l|}
\hline Zwroty & Liczba wystąpień w NKJP \\
\hline przejść na $t y$ & 249 \\
\hline być na $t y$ & 205 \\
\hline mówić na $t y$ & 69 \\
\hline zwracać się per $t y$ & 25 \\
\hline mówić per $t y$ & 20 \\
\hline zwracać się na $t y$ & 10 \\
\hline na $t y$ & 8 \\
\hline wypić na $t y$ & 4 \\
\hline pozostawać na $t y$ & 3 \\
\hline być na per $t y$ & 2 \\
\hline być na $t y$ & 2 \\
\hline per $t y$ & 2 \\
\hline przejść na per $t y$ & 2 \\
\hline walić na $t y$ & 2 \\
\hline pisać na $t y$ & 1 \\
\hline wyjść na $t y$ & 1 \\
\hline wywlec duszę na $t y$ & 1 \\
\hline
\end{tabular}

Z danych zebranych z NKJP wynika, że najczęściej występującym zwrotem jest przejść na ty (249), po którym uplasowały się być na ty (205) i mówić na ty (69). Występują również zwroty zwracać się per ty (25), mówić per ty (20), zwracać się na ty (10) oraz kilka innych.

Najwięcej przykładów pochodzi z literatury, kolejne miejsca zajmują teksty publicystyczne, quasi-mówione oraz literatura faktu. Wykres 1 przedstawia liczby odnoszące

\footnotetext{
${ }^{5}$ NKJP zawiera dwa wyszukiwarki: IPI PAN (Instytut Podstaw Informatyki Polskiej Akademii Nauk) oraz PELCRA (Polish and English Language Corpora for Research and Application). W niniejszej analizie skorzystano z wyszukiwarki PELCRA ze względu na rozmaitość opcji wyszukiwania.

${ }^{6}$ Wśród znalezionych tekstów korpusowych z hasłem na ty i per ty były również przykłady opisujące bycie z czymś na ty, przykładowo: $z$ ekonomia na ty. W niniejszych badaniach jednak nie zajmuję się tego typu tekstami, ponieważ większość z nich pojawia się w reklamach czy w tytułach wydarzeń i nie pokazują one bezpośrednio relacji międzyludzkiej, która stała się głównym przedmiotem moich zainteresowań naukowych.
} 
się do poszczególnych typów tekstu ${ }^{7}$ Można sądzić, że język literacki czy publicystyczny jest językiem wymyślonym przez pisarzy i nie przekazuje on spontanicznych wypowiedzi w żywym języku. Jednak z treści zawartych we fragmentach z NKJP można wydobyć ogólne postrzeganie rzeczywistości, ponieważ postacie czy sytuacje uformowane oczami autorów - pokazują pewny obraz relacji międzyludzkich kształtowanych przez użytkowników danego języka. Najlepszym materiałem językowym do badań przedmiotu byłyby oczywiście naturalne rozmowy na co dzień, jednak kwestie informacji osobistych oraz perspektywa etyki rodzą spore problemy z wykorzystaniem takich ,prawdziwych" danych językowych do badań naukowych. Istnieją liczne badania przeprowadzone za pomocą kwestionariusza czy wywiadu, lecz często wpływa na nie intencja badaczy, przez co uniwersalność takich materiałów językowych okazuje się ograniczona. Na potrzeby niniejszego artykułu wykorzystano zatem dane korpusowe, dzięki którym można zachować pewną obiektywność materiałów. Elementy istotne dla opisania relacji międzyludzkich, tak zasygnalizowane, mogą stanowić bazę do dalszych badań przedmiotu.

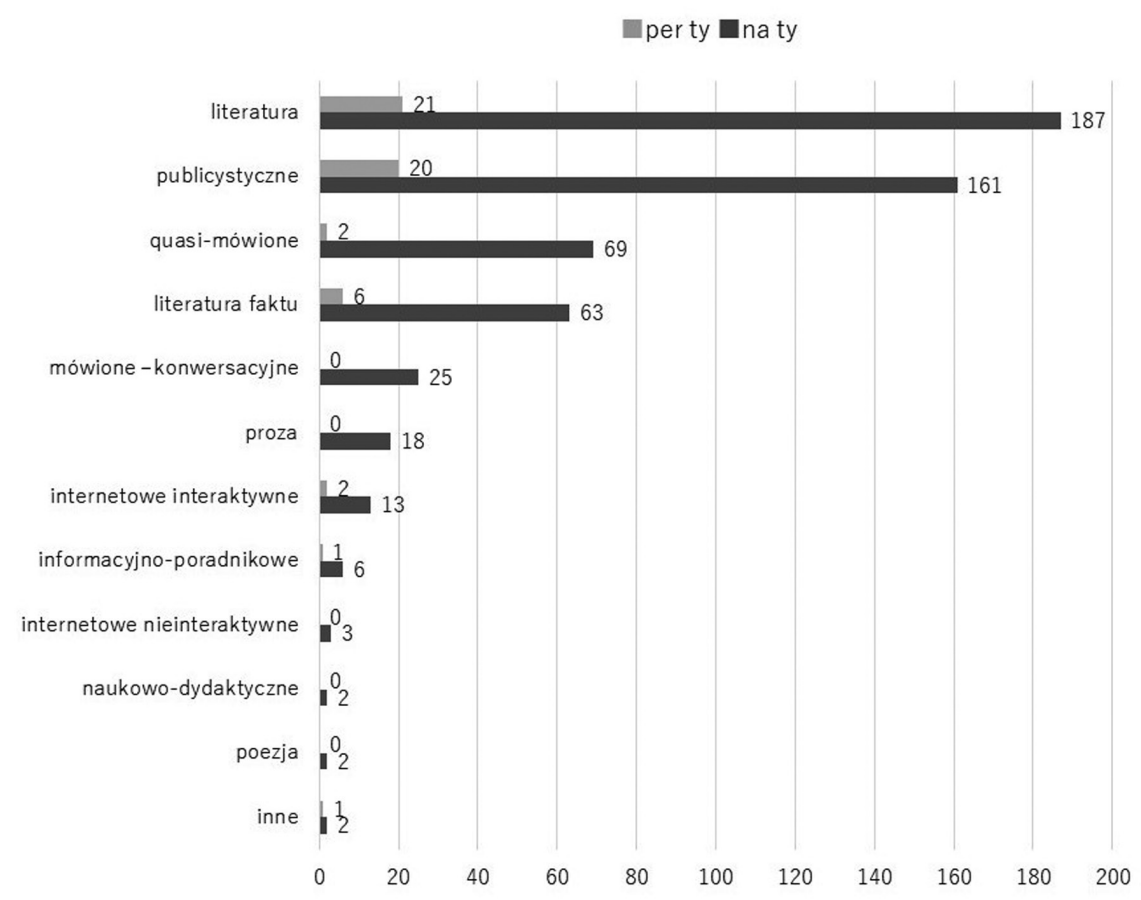

Wykres 1. Liczby poszczególnych typów tekstu (wśród 606 tekstów uzyskanych z NKJP)

\footnotetext{
${ }^{7}$ Wszystkie typy tekstów na wykresie zostały przedstawione zgodnie z podzielonymi przez zespół wykonawców NKJP gatunkami tekstów.
} 


\section{OBRAZ RELACJI NA TY W TEKSTACH KORPUSOWYCH}

Zgodnie z kierunkami wyznaczonymi przez rozważania polskich badaczy dotyczące relacji na $t y$, niniejsza analiza obejmuje m.in. następujące tematy:

- wspólne działania i korzyść rozmówców

- dążenie do swobody w komunikacji

- bliskość emocjonalna a obszar prywatności

- propozycja przejścia na ty.

Aby ograniczyć objętość niniejszej analizy, przedstawiono tylko wybrane przykłady z NKJP, za pomocą których można zasygnalizować elementy istotne dla opisywania relacji na ty.

\subsection{Wspólne dzialania i korzyść rozmówców}

W zebranych tekstach korpusowych można zaobserwować opisy ilustrujące wspólne działania i stanowiące czynnik solidarności. Poniższy fragment zawiera wyrażenie „wspólna praca”, o czym wspomniano w przedstawionych wcześniej cytatach z polskich tekstów językoznawczych:

1. Wspólna praca zbliża, więc przeszliśmy z tej okazji na „ty” [...].

W tym przykładzie rozmówcy zdecydowali się na przejście na ty z okazji wspólnej pracy. Można tę sytuację wyjaśnić wspólnotą profesjonalną, którą wymienia Łaziński jako jeden z czynników solidarności, czyli czynnik stosowania formy ty. Na podstawie powyższego fragmentu trudno określić środowisko, w którym znajdują się interlokutorzy, jednak można zasygnalizować element wspólnej pracy jako więź, która łączy ich w tej wspólnocie i skłania do przejścia na ty. W kolejnych tekstach również występuje zasada „robimy coś wspólnie” i na tej podstawie rozmówcy decydują się na przejście na ty:

2. - Słodzi pani? Może ciasteczka? - Koteczku - odezwała się Andżelika - jeśli mamy coś robić, to lepiej przejdźmy na ty . Będzie ci raźniej - popijając herbatę[,] Andżelika wodziła wzrokiem za krążącą po saloniku Anną T.

3. Popatrzyła na mnie uważnie i poprawiając włosy, opadające jej na czoło, zaproponowała, że skoro mamy za dwa dni razem wędrować po tajemniczych wnętrznościach góry, to może powinniśmy przejść na ,ty”.

Przykład 2. zawiera fragment „mamy coś robić”, a w przykładzie 3. odpowiednikiem staje się zwrot „razem wędrować”. To potwierdza, że w relacji na ty może istnieć więź dla korzyści, która przydaje się w realizowaniu wspólnego celu. Kiedy interlokutorzy uznają, że relacja na ty może wnieść korzyść dla dalszego etapu znajomości, następuje zmiana sposobu zwracania się do siebie wychodząca od każdej ze stron albo jedna z nich wychodzi z propozycją tej zmiany. Skrajnym przykładem takiej więzi dla korzyści może być nawiązanie relacji na ty w środowisku politycznym, co również można zaobserwować w tekstach zaczerpniętych z korpusu: 
4. Znał wszystkich finansistów Europy, przy czym z większością ludzi był na ty. [...] - Oni potrzebowali pieniędzy, zbliżały się wybory, a partia była uboga, on potrzebował zaplecza politycznego opowiada Pineiro.

5. Dziś wielu z nich piastuje wysokie stanowiska w administracji. Z większością ministrów szef GDS $^{8}$ jest na ty. Większość pierwszoligowych lobbystów ma w życiorysach polityczną działalność.

6. Dużo mówi się ostatnio o kuluarach polskiej polityki, relacjach towarzyskich w kręgach władzy. Wszyscy zastanawiają się, kto jest z kim ,na ty”, z kim się brata, a kogo nie lubi.

W przykładach od 4. do 6. hasło na ty występuje w kolokacji być na ty. W porównaniu z wyrażeniami połączonymi z innymi czasownikami, na przykład mówić na ty czy zwracać się na ty, być na ty bardziej podkreśla relację na ty jako pewien status, który jest korzystny i pomaga rozmówcom w realizowaniu współpracy, zwłaszcza w kontekście politycznym. W podanych przykładach relację na ty traktowano nie tylko jako rzeczywisty stan znajomości czy sposób, w jaki zwracają się do siebie politycy, lecz także jako podpowiedź o istnieniu wspólnych działań politycznych dla korzyści obu stron. Można powiedzieć, że taka wspólnota polityków należy do wspólnoty profesjonalnej, wspomnianej przez Łazińskiego, jednak przynależność do wspólnoty nie wpływa bezpośrednio na bycie na ty. Można przypuszczać, że rozmówcy będący we wspólnocie - przykładowo - pracy, mogą nie decydować się na stosowanie formy ty. Jako jeden z elementów decydujących o byciu w relacji na ty istotna jest zatem korzyść, która łączy uczestników tego typu relacji, i- tak jak pokazują przykłady - taka korzyść jest postrzegana najczęściej we wspólnocie pracy.

\subsection{Dążenie do swobody w komunikacji}

Drugim elementem, który stanowi czynnik stosowania formy ty, jest dążenie do swobody komunikacyjnej. Takiej swobody często wymaga wspólnota pracy, sprzyjająca powstaniu więzi dla korzyści, jednak także w sytuacjach, gdzie rozmówcy nie mają konkretnych działań wspólnych, czasem relacja na ty jest preferowana ze względu na większą swobodę w interakcji. Kolejne przykłady demonstrują swobodę i łatwość wypowiedzi, które wiążą się z relacją na ty:

7. Wszyscy mówią sobie per ty, są wobec siebie swobodni i równi.

8. Pytam dlatego, że jeden z przedstawicieli Agory mówił, iż państwo w redakcji, ale także z innymi osobami[,] używacie swobodnych form komunikacji, przechodzicie automatycznie na ty. Czy także z panią minister Jakubowską były to takie rozmowy, które należy uznać za, no może nie koleżeńskie, ale swobodne?

9. Lżej się spowiadać po sznapsie. I łatwiej wywlec duszę na ty niż na pan.

Przykład 7. obrazuje sytuację, gdzie wszyscy „mówią sobie per ty” i podkreślone okazują się swoboda oraz równość w relacji rozmówców. W przykładzie 8. również omawiane

\footnotetext{
${ }^{8}$ GDS - Grupa Doradztwa Strategicznego (firma lobbingowa).
} 
są „swobodne” rozmowy realizowane przez użycie formy ty. Mówienie na ty można by zatem traktować jako ułatwienie komunikacji, więc niektórzy decydują się na zwracanie się na ty tylko po to, aby mogli swobodnie prowadzić rozmowy. Przykład 9. nie zawiera przymiotnika 'swobodny', jednak przez nietypowe sformułowanie „wywlec duszę na ty” w połączeniu z przysłówkiem ,łatwiej” ten fragment również opisuje swobodę w komunikacji. W pracach polonistycznych można znaleźć uwagi językoznawców o tym, że napływ kultury zachodniej i amerykańskiej do polskiego społeczeństwa po zmianie ustrojowej doprowadził do wyeksponowania takich cech jak uproszczona grzeczność czy zminimalizowane okazywanie szacunku wobec drugiej osoby (Ożóg 2001, 80-84; Marcjanik 2015, 118-119). Ta tendencja jest obserwowana w różnych zachowaniach językowych, a jednym z nich mogłoby być właśnie dążenie do swobody komunikacyjnej przez mówienie na ty, które opisują niektóre teksty korpusowe, takie jak powyższe.

\subsection{Bliskość emocjonalna a obszar prywatności}

Warto pamiętać, że oprócz wspólnoty pracy, przez którą rozmówcy domagają się czasem swobody w komunikacji, istnieją jeszcze inne czynniki solidarności, wymieniane przez Łazińskiego w odniesieniu do semantyki solidarności Browna i Gilmana. Zwłaszcza wspólnotę rodzinną czy wspólnotę przekonań ${ }^{9}$ można by ująć jako wspólnotę często bazującą na więzi uczuciowej. Relacja na ty może się zatem wiązać ze zbliżeniem rozmówców na poziomie uczuciowym, w wyniku czego w niektórych sytuacjach rozmówcy decydują się na to przejście. Taka bliskość psychologiczna występuje w niektórych tekstach korpusowych. Przykładowo:

10. Piliśmy mądrość z jego ust, a on łaskawie nam pozwalał bratać się z sobą, był z nami na ty.

11,„Jeśli chcesz zarobić milion złotych, to nie gadaj, tylko weź się do roboty”. To było fajne. Czuło się jakąś więź z tymi ludźmi. Wokół uśmiechy, pochwały. Wszyscy na ty. Jak rodzina.

Te przykłady ilustrują relację na ty jako bliską i postrzeganą pozytywnie. Warto zwrócić uwagę na to, że w przykładzie 11. pojawia się pojęcie „rodzina” w opisie pozytywnego odbioru relacji na ty opartej na więzi uczuciowej. $Z$ tego kontekstu można zatem odczytać, że wspólnota rodzinna, którą wymienia Łaziński jako czynnik solidarności, może być rozumiana jako więź uczuciowa.

Bliskie relacje często wiążą się z długą znajomością rozmówców, którą Marcjanik wymienia jako jeden z czynników powodujących przejście na ty. Poniższe teksty z korpusu również pokazują stosunek między długością kontaktu a byciem na ty:

12. [...] ja od kilkunastu lat mam tę samą krawcową. W naszych kontaktach nastąpiła taka różnica, że kiedyś szyłam sobie coś u niej raz od wielkiego dzwonu, bo nie miałam pieniędzy. Teraz mam, to i jestem u niej często. Znamy się dobrze i od lat jesteśmy na „ty”.

\footnotetext{
${ }^{9}$ Wspólnotę przekonań mogą kształtować - przykładowo - poglądy polityczne, wartości religijne itd.
} 
13. [...] jesteśmy z księdzem Tadeuszem po imieniu. Wiem, że nie wszystkim czytelniczkom i czytelnikom może się spodobać to, iż człowiek świecki zwraca się do księdza per „ty”. Ale znamy się i przyjaźnimy tak długo, że byłoby to nienaturalne, gdybym nagle zaczął się zwracać do Tadeusza ,proszę księdza”.

Należy jednak zwrócić uwagę na to, że relacja na ty spowodowana przez długą znajomość nie zawsze oznacza bliskość rozmówców na poziomie uczuciowym. W niektórych przypadkach, tak jak obserwujemy w kolejnych przykładach korpusowych, nie znajduje miejsca więź uczuciowa i wtedy w relacji na ty nadal zostaje pewna granica prywatności:

14. Zresztą Opole jest tak małe, że wszyscy się w nim znają. My też jesteśmy na „ty”, a przecież nie jesteśmy bliskimi kolegami.

15. Zresztą nigdy nie rozmawiali o swoim życiu prywatnym. Mimo wielu wspólnie spędzonych godzin. Mimo że byli na ty i zdawali się zaprzyjaźnieni.

O obszarze prywatności w komunikacji wspomina Marcjanik w opisie symetrycznej relacji na ty (Marcjanik 2007, 36). Po obserwacji przedstawionych tekstów korpusowych pozostaje jednak wątpliwość w tej kwestii, ponieważ bycie na ty nie zawsze pozwala rozmówcom przekroczyć granicę prywatności. Z przytoczonych przykładów można przypuszczać, że wkroczenie w sferę prywatną jest możliwe wtedy, kiedy partnerów komunikacji łączy więź uczuciowa. Zdarzają się również sytuacje, w których relacja na ty między rozmówcami opiera się tylko na korzyści czy dążeniu do swobody, a nie na bliskości psychologicznej, i w takich sytuacjach prywatność może być dalej zachowana. Podział między byciem na ty a byciem na pan/pani nie pokrywa się do końca z granicą prywatności i wydaje się zatem, że uogólnienie charakterystyki relacji na ty wymagałoby jeszcze bardziej konkretnego uzasadnienia ${ }^{10}$. Przez przejście na ty dystans w komunikacji skraca się i przynajmniej pragmatycznie rozmówcy są równorzędni, jednak stopień prywatności może zostać określony na różnych poziomach.

\subsection{Propozycja przejścia na ty}

Nawiązaniem do tematu z poprzedniego podrozdziału stanie się tu omówienie zasad dotyczących propozycji przejścia na ty. Marcjanik w swojej monografii podaje warunki, pod którymi może ono nastąpić: wiek, stanowisko oraz płeć. Przeanalizuję zatem teksty korpusowe opisujące sceny przejścia na ty, z uwzględnieniem tych trzech elementów wymienionych przez badaczkę. Pierwsze przykłady dotyczą wieku rozmówcy:

16. Wiesz co? - rzuciła - [P]rzejdźmy na ty. Jestem od ciebie wystarczająco dużo starsza, a łatwiej się będzie gadać. Mam na imię Halina (Andrzej, bąknąłem).

\footnotetext{
${ }^{10}$ Badaczka definiuje relację na ty oraz przejście na ty, ,pomijając różnice indywidualne” (Marcjanik 2007, 36). Warto jednak wziąć pod uwagę również te pomijane przypadki, ponieważ przykłady z niniejszej analizy sugerują, że takie indywidualne sytuacje, w których rozmówcy w relacji na ty zachowują granicę prywatności, wydają się istotne dla definicji tej relacji.
} 
17. [...] przy naleweczce zaproponował w końcu, jako starszy, przejście na „ty” [...].

18. [...] sam zaproponował gronu młodych krytyków przejście na ty. Sytuacja powstała niezręczna, wspominał Erhardt, bo z jednej strony nie wypadało propozycji odmówić, z drugiej różnica wieku mocno młodzież krępowała.

W powyżej opisanych scenach przejście na ty proponuje osoba starsza, co zgadza się ze stwierdzeniem Marcjanik. Tak jak wspomniano, na podstawie tekstów z korpusu trudno odczytać dokładnie kontekst każdej z tych sytuacji, jednak można powiedzieć, że istnieje przynajmniej tradycyjna zasada wiekowa towarzysząca przejściu na ty. Kolejne przykłady również pokazują różnicę wieku między rozmówcami, mimo której czasami to przejście się realizuje:

19. Mimo różnicy wieku zaprzyjaźniliśmy się, przeszliśmy na ty.

20.W przypadku osób zupełnie obcych zawsze najpierw trzeba poświęcić trochę czasu na likwidowanie dystansu między nami. Ja m.in. staram się, niezależnie od wieku, przejść na „ty”, to pomaga.

Powyższe fragmenty nie przedstawiają propozycji przejścia na ty wychodzącej od osoby starszej, jednak jako przykładowe opisy dotyczące wieku rozmówców, którzy przechodzą na ty, pokazują istotne sceny. W przypadku tekstu 19. czynnikiem przejścia na ty jest więź uczuciowa określona czasownikiem 'zaprzyjaźnić się', z kolei w tekście 20. można odczytać pozorną więź dla swobody. Niektórzy językoznawcy wymieniają różnicę wieku jako jeden z czynników, które czasem mogą zaprzeczać zasadzie wspólnoty powodującej przejście na ty (Grybosiowa 2002, 5), jednak powyższe przykłady pokazują, że czasami zdarza się odwrotna sytuacja. Można powiedzieć, że istniejące więzi między interlokutorami również mogą zaprzeczać ogólnie przyjętej normie, zgodnie z którą przy dużej różnicy wieku trudno przechodzi się na ty.

Następnym elementem, który uwzględniam w analizie, jest wpływ stanowiska w hierarchii służbowej lub zawodowej rozmówców na przejście na ty. W poniższym przykładzie można zaobserwować hierarchię między dwiema osobami, które przechodzą na ty:

21. Kiedy Lech Bądkowski zaproponował mi przejście na ty, był rzecznikiem prasowym [„,]Solidarności["], a ja początkującym dziennikarzem. Postawił pół litra i poczęstował tabaką. Byłem dumny [...].

Tutaj adresat propozycji przejścia na ty jest z tego „dumny” i pozytywnie odbiera intencję proponującego. Pozytywną ocenę propozycji przejścia na ty ze strony osoby wyższej rangą opisuje również poniższy tekst $\mathrm{z}$ korpusu:

22. Podwładni dodają, że dość szybko przechodził na „ty”. - Dobry wujek, o którym wszyscy wiedzieli, że na biznesie zna się słabo, ale porządnie wszystko organizował.

Ten przykład ilustruje relację służbową między przełożonym a podwładnym i pokazuje pozytywny obraz tego zjawiska. Niektóre sytuacje jednak mogą być niezręczne dla odbiorcy propozycji przejścia na ty ze względu na - przykładowo - status społeczny 
proponującego. W następnych tekstach obserwujemy skrępowanie odbiorców propozycji spowodowane przez hierarchię między rozmówcami:

23.Jerzy Trela już trzy razy proponował, żebyśmy przeszli na ty, a mnie jest ciężko mówić do niego nawet panie Jurku. Ciśnie mi się cały czas na usta [,,]panie profesorze[”] - śmieje się Sonia.

24- Mam zaszczyt - powiedział - zaproponować panu przejście na ty. Wirth miał chaos w głowie, kiedy trącał się kieliszkiem ze swoim dawnym opiekunem.

Czynniki skrępowania przy przejściu na ty są różne ${ }^{11}$ i mogą spowodować dyskomfort także na dalszym etapie znajomości. Ze względu na drastyczność zmiany sposobu zwracania się niektórzy decydują się na kontynuację stosowania formy pan/pani. Z reguły reakcją na propozycję przyjścia na ty jest zgoda (Marcjanik 2006, 275; 2007, 43), jednak zdarzają się sytuacje, gdzie następuje nieprzyjęcie propozycji spowodowane przez poczucie skrępowania odbiorcy. Ciekawym przykładem jest fragment 23., gdzie pojawiają się dwa typy formy adresatywnej: „panie Jurku” oraz „panie profesorze”. W polskim środowisku akademickim norma nakazuje użycie tytułów naukowych, w związku z czym zwracanie się do profesora przez ,panie Jurku” w tej sytuacji jest niestosowne. Użycie formy z imieniem, nawet w połączeniu z członem pan/pani, może być krępujące, ponieważ w polskiej kulturze jest ona odbierana jako forma pośrednia ${ }^{12}$.

Ostatnim z zanalizowanych elementów decydujących o tym, kto powinien zaproponować przejście na ty, jest płeć rozmówców. Według Marcjanik inicjatywa powinna wyjść ze strony kobiety i niektóre teksty znalezione w korpusie potwierdzają tę świadomość użytkowników języka polskiego. Przykładowo:

25. Pomiędzy październikiem a grudniem 1954 przeszliśmy na ty. Jarosław mi to zaproponował, thumacząc się, że wprawdzie inicjatywa powinna należeć do kobiety, ale usprawiedliwia go różnica wieku.

26.Zastanawiał się, kto powinien zaproponować przejście na ty. Z jednej strony, ona jest kobietą, z drugiej, on jest starszy o jakieś dziesięć lat. Głupia sytuacja. Może jak się spotkają następnym razem, to jakoś samo wyjdzie.

27. Paulina nie wie, czy powinna zaproponować przejście na „ty”. Być może Karol na to czeka [...].

Scena opisana w tekście 25. pochodzi z 1954 roku, zatem niewykluczone, że taka tendencja już wyszła z normy obyczajowo-językowej. Można jednak powiedzieć, że w polskim społeczeństwie za tradycyjne podejście wciąż uznaje się pierwszeństwo kobiet podczas przejścia na ty. $\mathrm{W}$ tekście 27 . również obserwujemy to zjawisko między kobietą a mężczyzną i tutaj kobieta sama się zastanawia nad propozycją. Temat wpływu płci wymaga dalszych badań opartych na najnowszych danych językowych, ponieważ tego typu przykładów uzyskanych z korpusu jest dosyć mało i nie pozwalają

\footnotetext{
${ }^{11}$ Oprócz hierarchii, także różnica wieku czy formalność sytuacji mogą spowodować poczucie niezręczności przy przejściu na ty.

${ }^{12}$ W swojej monografii wspomina o tej formie Marcjanik (2007, 47-50).
} 
one na dokładne określenie kontekstu każdej sceny, przez co trudno odczytać ogólną tendencję.

\section{PODSUMOWANIE}

Oczywiście, że trudno zdefiniować jednoznacznie relację na ty w kontekście polskim tylko na podstawie tekstów zaczerpniętych z korpusu, ponieważ rodzaje wyznaczników społecznych wpływających na nią okazują się rozmaite i nie zawsze odzwierciedla je zachowanie językowe. Jednak analiza tekstów z NKJP pozwoliła zasygnalizować elementy budujące relację na ty, czynniki powodujące przejście na ty oraz warunki umożliwiające ten akt. Przykłady uwzględnione w analizie dowodziły, że relacja na ty ujawnia niejedno oblicze w dwukierunkowych relacjach międzyludzkich. Warto zatem spróbować odpowiedzieć na pytania przedstawione na początku niniejszego artykułu: (1) jakie znaczenie ma bycie z kimś w relacji na ty; oraz (2) co oznacza przejście na ty i w jakich warunkach ono następuje. W odpowiedzi na pierwsze pytanie można by wymienić trzy rodzaje więzi: więź dla korzyści, więź dla swobody oraz więź uczuciową. Wszystkie trzy podkreślają, co łączy partnerów komunikacji. Mogą one również współistnieć w danej relacji. W relacji na ty czasem - tak jak obserwowano w niektórych przykładach z niniejszej analizy - mimo więzi zostaje jeszcze granica prywatności, której nie należy przekraczać. Stąd można by wnioskować, że przejście na ty nie zawsze oznacza możliwość wkraczania w obszar prywatności partnera rozmowy, co może stanowić odpowiedź na drugie postawione pytanie. Przejście na ty należałoby zatem traktować jako akt potwierdzający istnienie jednej lub kilku z powyższych więzi. Teksty zebrane z korpusu wskazują, że propozycja przejścia na ty może wyjść od osoby starszej, od kogoś wyższego stanowiskiem lub od kobiety - tak jak twierdzą polscy badacze. W niektórych fragmentach obserwowano poczucie skrępowania odbiorcy z powodu propozycji przejścia na ty, co stanowi również istotny temat do dalszych badań zarówno jakościowych, jak i ilościowych. Pierwszeństwo kobiet przy przejściu na ty można zaobserwować w tekstach korpusowych, jednak warto byłoby sprawdzić najnowszą tendencję za pomocą wywiadu lub ankiety skierowanej do użytkowników polszczyzny.

\section{BIBLIOGRAFIA}

Brown, R., i A. Gilman. 1960. „The Pronouns of Power and Solidarity”. W Style in Language, red. T.A. Sebeok. Cambridge: MIT Press, 253-276.

Grybosiowa, A. 2002. „Nowe sytuacje - nowe zachowania grzecznościowe”. Poradnik Językowy 2: 3-8. Handke, K. 2021. Socjologia języka, wyd. 1 (2. dodruk). Warszawa: Wydawnictwo Naukowe PWN. Hudson, R.A. 1991. Sociolinguistics, wyd. 2. Cambridge: Cambridge University Press. Huszcza, R. 1980. „O gramatyce grzeczności”. Pamiętnik Literacki 71 (1): 175-186.

Huszcza, R. 1996. Honoryfikatywność. Gramatyka, pragmatyka, typologia. Warszawa: Wydawnictwo Naukowe PWN. 
Huszcza, R. 2000. „Jeszcze o honoryfikatywności polskich zaimków osobowych”. Poradnik Językowy 6: 21-30. Jabłoński, A. 2017. „Wewnątrz i na zewnątrz kultury. Komu potrzebna jest «grzeczność»?”. Tertium Linguistic Journal 2 (1): 129-141.

Kotikowa, W. 2002. „Formy adresatywne we współczesnym języku rosyjskim, polskim i w amerykańskim wariancie języka angielskiego. Charakterystyka socjolingwistyczna”. Poradnik Językowy 1: 43-51.

Łaziński, M. 2006. O panach i paniach. Polskie rzeczowniki tytularne i ich asymetria rodzajowo-ptciowa. Warszawa: Wydawnictwo Naukowe PWN.

Marcjanik, M. 1997. Polska grzeczność językowa. Kielce: Wyższa Szkoła Pedagogiczna im. Jana Kochanowskiego.

Marcjanik, M. 2006. „ABC grzeczności językowej”. W Polszczyzna na co dzień, red. M. Bańko. Warszawa: Wydawnictwo Naukowe PWN.

Marcjanik, M. 2007. Grzeczność w komunikacji językowej. Warszawa: Wydawnictwo Naukowe PWN.

Marcjanik, M. 2014. Stownik językowego savoir-vivre'u. Warszawa: Wydawnictwa Uniwersytetu Warszawskiego.

Marcjanik, M. 2015. „Współczesna etykieta językowa - zmierzch wartości?”. Studia Medioznawcze 4 (63): $115-119$.

Markowski, A. 2018. Kultura języka polskiego. Teoria. Zagadnienia leksykalne, wyd. 2. Warszawa: Wydawnictwo Naukowe PWN.

Narodowy Korpus Języka Polskiego. http://www.nkjp.uni.lodz.pl/ (9 marca 2021).

Nowakowska, M. 2011. „Podstawy etykiety językowej w wybranych podręcznikach do nauki języka polskiego jako obcego". Acta Universitatis Lodziensis. Ksztatcenie Polonistyczne Cudzoziemców 18: 201-209.

Ożóg, K. 2001. Polszczyzna przełomu XX i XXI wieku. Wybrane zagadnienia. Rzeszów: Stowarzyszenie Literacko-Artystyczne „Fraza”.

Ożóg, K. 2018. „Słowa dobre i słowa złe w komunikacji między Tobą a mną”. W W obliczu emocji, red. A. Myszka, i K. Bieńkowska. Rzeszów: Wydawnictwo Uniwersytetu Rzeszowskiego, 15-30 (Głos Język - Komunikacja, t. 5).

Pisarkowa, K. 1979. „Jak się tytułujemy i zwracamy do drugich”. Język Polski 1: 5-17.

\section{WYKAZ ŹRÓDEL}

Materiały z Narodowego Korpusu Języka Polskiego:

1) Roman Radoszewski, Czesław Niemen: kiedy się dziwić, 2004.

2) Btahostka, 1997.

3) Maciej Pinkwart, Dziewczyna z Ipanemy, 2003.

4) Piotr Pytlakowski, Pośrednik, 2001.

5) Bianka Mikołajewska, Inne rośliny lub czasopisma, 2003.

6) Politycy zwani inaczej, 2003.

7) Małgorzata Szejnert, Czarny ogród, 2007.

8) Kancelaria Sejmu Rzeczypospolitej Polskiej, 2003.

9) Jarosław Abramow-Newerly, Młyn w piekarni, 2002.

10) Zygmunt Kubiak, Przestrzeń dziet wiecznych: eseje o tradycji kultury śródziemnomorskiej, 1993. 
11) Sen o finansowej potędze, 1999.

12) Paweł Nassalski, Sprzedajemy też garsonki, 2000.

13) Tadeusz Isakowicz-Zaleski, Moje życie nielegalne, 2008.

14) Marek Świercz, Brałem, ale nie dla siebie, 2004.

15) Monika Rakusa, Żona Adama, 2010.

16) Jerzy Sosnowski, Linia nocna, 2002.

17) Rafał A Ziemkiewicz, Żywina, 2008.

18) Mariusz Urbanek, Waldorff, ostatni baron Peerelu, 2008.

19) Janusz Miliszkiewicz, Przygoda bycia Polakiem, 2007.

20) Ewa Stołowska, Bydgoszcz: Photo Day 7.0. „Fotodejowiec” zrobił sesję ślubna w Łuczniczce, 2010.

21) Wiek męski z tabakiera, 2002.

22) Joanna Cieśla, Mechanik prezydenta, 2008.

23) Huzarska-Szumiec Magda, Wyjść zza kulis, 2002.

24) Marek Krajweski, Festung Breslau, 2006.

25) Irena Szymańska, Miałam dar zachwytu, 2001.

26) Zygmunt Miłoszewski, Uwiktanie, 2007.

27) Anna Onichimowska, Trzecie oko, 2009.

\title{
The Relation on a First-name Basis in the Light of Corpus Data
}

Keywords: addressing forms, linguistic corpus of Polish, transition to a first-name basis, interpersonal relations.

\begin{abstract}
The article presents an analysis of corpus texts describing the relation on a first-name basis in Polish society. The research is based on over 600 texts with the phrases na ty and per ty (eng. on a first-name basis) taken from the linguistic corpus of Polish. Such texts allow the author to illustrate the general frame of the relation on a first-name basis. The analysis has shown that the interlocutors in this type of relation share one or more bonds of the following kinds: a bond for benefits, a bond for ease of communication, and an emotional bond. The bond for benefits connects interlocutors in order to achieve a common goal, which can sometimes be observed as a relation on a first-name basis among politicians. Some texts have shown that people decide to switch to a first-name basis to simplify their interaction. The emotional bond, which also connects people addressing each other on a first-name basis, may be related to family groups or a longterm relation between interlocutors. Transition to a first-name basis can be treated as an act confirming the existence of one or more of the above-mentioned bonds, which does not always mean permission to cross the border of privacy. The results of the analysis have also shown that social markers such as age, hierarchy, and gender may cause uncomfortable feeling when switching to a first-name basis. The elements indicated by this analysis provide an important perspective for further research.
\end{abstract}

